\title{
What Drives University-Industry Collaboration
}

\author{
Suparno $^{1}$, Harsoyo², Adi Ekopriyono ${ }^{3}$ \\ * Faculty of Social and Political Sciences, 17 August 1945 University Semarang \\ ** Faculty of Economics and Business, 17 August 1945 University Semarang
}

DOI: 10.29322/IJSRP.12.01.2022.p12125

http://dx.doi.org/10.29322/IJSRP.12.01.2022.p12125

\begin{abstract}
This study aims to analyze the implementation of collaboration between private universities and industry at the faculty level to improve the quality of graduates and test an effective collaborative learning model between faculty and industry. The research was conducted in six private universities in Central Java, with a qualitative approach through interviews. The informants consisted of the head of the academic field, the Institute for Research and Community Service (LPPM), and the head of the field of cooperation. The conclusion obtained is that collaboration will be mutually beneficial if it is managed properly and anticipates matters related to the low interaction between faculty and industry. There are still differences that hinder the collaboration process and the achievement of goals. Therefore, faculty and industry need to develop capabilities in research and find the best solutions.
\end{abstract}

Index Terms- Collaboration, quality of graduates, faculty, industry.

\section{INTRODUCTION}

$\mathrm{T}_{\mathrm{l}}^{\mathrm{h}}$ he actual issue of higher education is Merdeka LearningIndependent Campus, abbreviated as MBKM (Merdeka Belajar-Kampus Merdeka), as stated in the Minister of Education and Culture Regulation Number 3 of 2020 concerning National Standards for Higher Education. There are four main MBKM programs, namely the ease of opening new study programs (Program Studi - Prodi), changes to the higher education accreditation system, the convenience of state universities becoming legal entities, and the right to study for students to take three semesters outside their study program.

It is stated that universities are required to facilitate the right for students to take Semester Credit Units (Satuan Kredit Semester - SKS) outside of universities for a maximum of two semesters or equivalent to 40 credits and take credits in different study programs at the same university for one semester or equivalent to 20 credits. The program is in the form of an internship work practices, teaching assistance in education units, humanitarian projects, entrepreneurial activities, research, student exchanges, building villages/thematic real work courses, and independent project studies.

This policy requires a change in a linear mindset that tends to be straight-forward to a lateral mindset that is creative-innovative with unconventional methods. This is the reform of higher education to anticipate the fast- changing times. The objectives of MBKM include liberating students and lecturers from the shackles of thoughts that hinder creativity and innovation. Minister Nadiem
Makarim said that the concept was inspired by $\mathrm{Ki}$ Hajar Dewantara's philosophy, namely freedom and independence. Ki Hajar's philosophy, among others, is to give students the freedom to develop creativity and be able and strong to stand on their own without depending on others.

In the context of MBKM, cognitive-class-oriented learning theory is not enough to improve the competence of graduates to answer the challenges of the times. Times have changed, so the mindset of students and lecturers must change towards affectivepsychomotor. The teaching-learning process is no longer limited to classrooms, but reaches the "outside world", from outside the study program, outside universities, to the industrial world.

Opportunities for students to take credits in different study programs are more in line with the challenges of the times increasingly complex, when a problem is no longer sufficiently approached by one discipline. Students need to have broader competencies, not just being limited to one discipline or at least understanding and understanding other fields of science.

There is no need for excessive concern that this policy will cause graduates' competencies to become more generalist, less specific in science. Cross Study Programs will actually enrich students' scientific insights, which will become social capital to navigate a better life met with various challenges. Interdisciplinary approaches are becoming more relevant; "horse glasses" need to be replaced with "helicopter view."

Internships or internships will encourage students to have work experience in preparation for real life. Entrepreneurship activities train them to become entrepreneurs who are smart to see opportunities, are creative, innovative, and dare to take measured risks.

All of this opens up opportunities for students to gain empirical experience in addition to theoretical in class. That is experiential learning, which is a holistic model of the learning process when humans learn, grow, and develop. According to the United States education figure David Allen Kolb (1984), experience plays an important role in the learning process that distinguishes it from other learning theories, such as cognitive learning theory or behaviorism.

The MBKM education model is in accordance with the characteristics of millennials, including liking work experience and not liking to be tied down. They will find their "world" that is freedom and independent by gaining internship experience, entrepreneurship, or being involved in humanitarian projects, as well as studying other fields of knowledge.

Minister Nadiem wants a paradigm and concept change, so that students do not only understand one discipline, because the challenges they face in real life after graduation are very complex. 
For lecturers, MBKM encourages them to be more open to the world outside the classroom and outside the campus. Opportunities are open for lecturers to carry out activities on other campuses based on the field of science, work as practitioners in the industrial world or foster students who have achieved the lowest achievements at the national level. This means that lecturers are also required to let go of the scientific ego mindset. The MBKM policy is not without its challenges. Cross-study policies, internships, and opportunities for lecturers to teach outside the campus need the right curriculum in accordance with MBKM. Therefore, universities are currently busy updating or developing curricula and trying to implement these policies in the teaching and learning process.

Collaboration between faculties and the business and industrial world (Dunia Usaha Dunia Industri - DUDI) is a collaboration that is more applicable than collaboration at the university level. Usually, collaboration at the faculty level begins with a cooperation agreement (Perjanjian Kerja Sama - PKS) which has been covered by an Memorandum of Understanding $(\mathrm{MoU})$ at the university level. Collaboration at the faculty level is more technical in nature, for example related to the curriculum. Faculties, through study programs, must develop curriculum, semester learning plans (Rencana Pembejaran Semester - RPS) that are in accordance with industry needs.

The MBKM policy is in line with Law Number 20 of 2003 concerning the National Education System. Article 4 paragraph 6 explains that education must be carried out by empowering all levels of society by optimizing the role of the community in the process of providing quality education.

Problems in the teaching and learning process in universities are related to human resources (HR), educational facilities and infrastructure, lack of government and community commitment in improving the quality of education, low public awareness of education levels, community culture that is different from educational culture. (Sugiyanti et al., 2013). Higher education is an integral part of the skills and innovation supply chain for businesses and is not a supplier-buyer transaction, nor is it the acquisition of a single product or service, but is multidimensional, sustainable, quality and durable. These attributes can only be created through university-industry collaboration (Wilson, 2012).

\section{IDENTIFY, RESEARCH AND COLLECT IDEA}

\section{1) Formulation of the problem}

Based on this description, the essence of the problem of this research is that there is no good cooperation between the faculty and DUDI. The formulation of the problem can be translated into research questions, as follows:

1. How to implement collaboration between faculty and DUDI to improve the quality of graduates?

2. What is an effective collaborative learning model between the faculty and DUDI?

\section{2) Research purposes}

Based on the research questions, the objectives of this research are:
1. Knowing the implementation of collaboration between faculties and DUDI to improve the quality of graduates

2. Finding an effective collaborative learning model between faculty and DUDI

\section{3) Literature review}

Collaboration between universities as higher education institutions and industry is important, because through collaboration solutions can be created for problems that occur in the fields of science and social, economic, and political agendas, such as democracy, sustainable development, and cultural understanding and integration. University and industry collaboration as scientific collaboration is defined from the point of view of behavior, task, and social background (Sonnenwald, 2007).

Universities are not only responsible for developing human resources (main mission: education) and generating new knowledge (second mission: research), but also must be involved in regional development and regional development (as the third mission). The third mission for universities to actively participate in regional development requires to act more in entrepreneurship development, such as creating spin-offs, promoting an entrepreneurial culture among students, and/or participating in the elaboration of smart specialization strategies (Fonseca, 2019).

In modern management, collaboration between universities and industry is understood as the implementation of the organization's vision and mission, and there is an understanding in the management and development of synergized inter-institutional programs. Therefore, among partnering institutions there must be a main actor in the activity, who is responsible for the success of the program.

Scientists have a high commitment to collaboration. The strengths and weaknesses of each institution are used as the basis for the realization of the spirit of cooperation to share in order to complement each other, add to each other, and benefit each other (mutualism). The partnership also has the principle of mutual understanding between partners in its implementation, which includes: the principle of participation, the principle of mutual cooperation, the principle of transparency, the principle of law enforcement; rights and obligations, leading to right-obligations, rewards and punishments, and the principle of sustainability (Healy et al., 2014).

The results of research by Draghici et al., (2015) state that there are six keys to realizing effective collaboration, namely: (1) universities have structures that support research projects efficiently; (2) effective and capable project management communicate and exercise good supervision; (3) growing young researchers who are able to identify the economic environment; 4) build new partners and support the existence of projects to seize opportunities; (5) organizational culture becomes an important pillar, where universities have openness in collaborating with industry; and 6) strategy dissemination become a force to share research results and become an important element in the promotion of research results to attract new partners.

The findings related to the key success factors for the effectiveness of collaboration between universities and industry, can be seen in table 1 below: 
Table 1: State of the art collaboration between universities and industry

\begin{tabular}{|c|c|}
\hline Description & Indicator \\
\hline $\begin{array}{l}\text { Five (5) important items related to } \\
\text { business and university collaboration } \\
\text { (Iqbal et al., 2015) }\end{array}$ & $\begin{array}{l}\text { 1. Curriculum design, development and outreach } \\
\text { 2. Graduates ready for work } \\
\text { 3. Student exchange and mobility program } \\
\text { 4. Continuing education and lifelong learning } \\
\text { 5. Entrepreneurship education }\end{array}$ \\
\hline $\begin{array}{l}\text { Eight (8) items cooperation university } \\
\text { and industry (Wilson, 2012) }\end{array}$ & $\begin{array}{l}\text { 1. Research and development collaboration } \\
\text { 2. Academic and student mobilization } \\
\text { 3. Commercialization of research results } \\
\text { 4. Curriculum development } \\
\text { 5. Learning all the time } \\
\text { 6. Entrepreneurship development }\end{array}$ \\
\hline $\begin{array}{l}\text { Four (4) evaluation items to assess the } \\
\text { strength of university-industry } \\
\text { collaboration (Ivascu et al., 2016). }\end{array}$ & $\begin{array}{l}\text { 1. Sharing knowledge } \\
\text { 2. Culture } \\
\text { 3. Financial support } \\
\text { 4. Communication }\end{array}$ \\
\hline $\begin{array}{l}\text { Five (5) items to be implemented in } \\
\text { university-industry collaboration } \\
\text { (Banal-Estañol et al., 2015) }\end{array}$ & $\begin{array}{l}\text { 1. Curriculum management } \\
\text { 2. Management of education personnel } \\
\text { 3. Utilize educational staff effectively } \\
\text { 4. Finance and financing management } \\
\text { 5. Management of facilities and infrastructure is carried out in } \\
\text { procurement and maintenance }\end{array}$ \\
\hline
\end{tabular}

The faculty curriculum must always be adapted to the dynamics of changes that occur holistically, so as not only to develop intellectual intelligence, but also the spiritual and emotional intelligence of students. A holistic curriculum with a contextual approach is needed to create a niche without compromising scientific goals or basic skills in their respective scientific fields (Hamalik Oemar, 2007).

Faculty and industry collaboration is important to do, because it can create solutions to problems faced in the field of science and problems on other agendas, including sustainable development, cultural understanding and integration as well as problems of democracy. Thus, the meaning of collaboration scientifically can be viewed from the point of view of behavior, social background and tasks (Sonnenwald, 2007).

Industry partners provide opportunities for students to improve their competencies through internships and conducting various types of training related to the dynamics of work, business and other things about about the company. This can be done in various ways, including conducting visits, internships, discussions with business practitioners, all of which are not obtained by students from campus. Industrial partners can also provide financial assistance to campuses through students for research and community service activities for universities to the faculty and study program levels. On the other hand, industry can benefit from research and technology development, which can help reduce research costs for industry. World industry can take advantage of the results of these new researches and discoveries, so that they are useful in the development of production processes and new products (Fernandez, 2015).

Collaboration can also generate expertise/skills, resulting in superior performance. Superior skills are distinctive competencies that can support positional advantage, which are expressed as performance outcomes that include customer satisfaction and loyalty. Collaborative activities require innovative work behavior, which is analogous to good interpersonal relationships through the exchange of high-quality team members and relationships between co-workers, as well as between work teams and team organizations (Zakaria et al., 2004).

This is to encourage innovation in the team and/or do the same to achieve predetermined organizational targets (Pudjiarti \& Hutomo, 2020). Many studies have shown that companies that collaborate with universities have a higher level of productivity than companies that do not have collaboration (Law \& Chuah, 2004). Collaborating companies can enjoy greater advantages in terms of research and development (R\&D) and are able to produce quality products at competitive costs.

Collaboration can be effective if it fulfills several assumptions, namely: experts and practitioners can apply the findings of researchers and the results of collaboration operationally provide a significant impact on the expected target.

\section{4) Method}

The method applied is adapted to the research objectives, namely: analyzing the implementation of faculty-industry collaboration to improve the quality of graduates and develop collaborative learning models effectively. The research uses a descriptive qualitative method that focuses on the implementation of faculty and industry collaboration. Researchers observe social facts that occur and at the same time serve as guidelines for interviews in the field according to the degree of change desired in the implementation of this program.

The research was conducted at six private universities (PTS) in Central Java, namely Upgris, Universitas Katolik (Unika) Soegijapranata, Universitas Dian Nuswantoro (Udinus), Universitas Muhammadiyah Semarang (Unimus), and Universitas Satya Wacana $(U K S W)$ Salatiga. The types of data collected are 
secondary and primary data. Research informants are parties who sit at the leadership level who know the problem cooperation college and industry, namely the chancellor, vice chancellor for academics, Institute for Research and Community Service (Lembaga Penelitian dan Pengabdian Masyarakat - LPPM), and MBKM Bureau at the university level.

Selection of informants using a purposive system, through a process snowball (Sugiyono, 2014), while collecting data through in-depth interviews, observations, and documentation. The next technique is the stage of reducing data, presenting (displaying) data, interpreting, concluding and verifying, increasing the validity of the results, then interpret data results. Data analysis techniques through the stages: reduction; serve; drawing conclusions and verification (Milles and Huberman, 2014). Data reduction is the process of selecting, simplifying, abstracting and transforming, followed by drawing conclusions through the inductive method, namely the process of collecting data and specific facts and then making general conclusions as a result of research.

\section{STUDIES AND FINDINGS}

\section{A. Research Result}

Faculty and industry collaboration provides an opportunity for all elements in the faculty to take solutions in collaboration with industry. Industry sees research and development produced by universities, for example model findings, innovations, patents, products. These findings are quite expensive investments because the process of carrying out research requires time, energy, and mental as well as risk because this study can be successful and may also fail or fail. Therefore, the presence of the government, in this case Ministry of Education and Culture much needed through the provision of research grants.

Collaboration between universities and industry is a platform for all campuses to offer solutions that are considered applicable to industry, so that not only big campuses can do it, but all campuses. This collaboration is expected to motivate faculties to compete in offering innovations or ideas to industry that can provide solutions to problems in the industrial world. In addition, industry can also offer business problems so that research conducted by universities is more relevant to handling these problems. Thus, research by lecturers with innovative findings can bridge industry with universities, or also known as link and match between the two.

Universities and industry collaborating scientifically can pursue collaboration in a variety of ways and levels. Garrick et al. (2004) suggested that these interactions were classified in four ways, namely: collaborative teaching and learning; research and development collaboration; business development collaboration; and community, industry, and regional development collaborations.

Collaboration between universities and industry is based on the analysis of data obtained through observation and found a series of strong evaluation metrics, which have the capacity to assess the strength of collaboration between universities (in this case faculty) and industry, namely:

1. Evaluation of collaboration parameters, such as knowledge sharing, culture, financial support, communication, and barriers.
2. Success factors: related to factors that have contributed to the development of cooperation between two parties in a relationship that is based on innovative findings and produces win to win solutions.

3. Tangible outcome: results obtained from collaboration between universities and industry/industrial partners. Tangible output is the main pillar of the industrial environment, while for universities it is the reputation and image created.

4. Barriers: found a number of inner bottleneck cooperation between industry and academia.

Knowledge transfer plays an important role in this collaboration. Therefore, the emphasis on organizational culture greatly contributes to building innovation. The way of creating organizational culture leads to better transfer and exploitation of knowledge produced by universities to stimulate innovation. In this case, Ivascu et al., (2016) suggest five stages, namely: opportunities for the company, identification of business needs, focus on meeting the needs and opportunities of business partners, co-creation (partners create opportunities for innovation processes, products or markets, and commercialization as the main goal of industrial partners). The next stage is: active engagement of partners in collaboration to achieve goals and identification of elements that contribute to value creation in university and industrial partners.

Strategic planning that is concentrated on cooperation focuses on collaborative learning processes, partnership patterns, and information systems related to communication and information distribution based on Cisco Certified Network Professional (CCNP) Enterprise, which is a technical certification that proves one's expertise in managing network solutions in a company. The final goal is to create a strategic planning process for university collaboration, so that the resulting output is a strategic plan to optimize cooperation.

Through increasing the role and development in the field of education, human resources are realized as development subjects who have broad insight and an adequate level of professional expertise. Human resources who are able to compete are expected to be able to explore, utilize, develop, and preserve the potential of natural and human resources in the region in competition in the global market.

The role of universities in increasing competitiveness at the national level and contributing to developing the nation's economy is highly dependent on the innovations or findings of universities. The industry's new findings are very useful according to market needs and are strongly influenced by the results of higher education research.

Santoso (2008) states that universities can be regarded as research institutions, so in the industrial cycle starting to make new products must be in accordance with market needs. In this case, universities have a role as institutions that carry out research and development for new products. Research institutes really need money to conduct research, meanwhile almost all industries are not yet equipped with research institutes, so universities must act as research institutes in industries.

Various activities that have been carried out by universities in an effort to explore options and establish harmonious relationships with industry still face many challenges, including: 
1. There is still a need for improvement in terms of quantity and quality of cooperation with various parties; central, regional and local governments, as well as industry,

2. Difficulty in finding industry partners who are willing to cooperate in the context of collaborative research,

3. There is still a limited network of campus academics with business people, both domestically and abroad.

4. Initiatives to create collaboration in terms of the role of industry, for example asking business actors to teach certain subjects as practicing lecturers and vice versa, universities also send lecturers to study in an industrial environment.

Emerging policy approaches to promote faculty-industry collaboration knowledge transfer include:

1. Support for the co-creation of science industry knowledge. The notion of co-creation emphasizes the interactive and collaborative nature of knowledge transfer between universities and industry. For example, policymaking for collaborative research centers such as the Centers of Competence and Centers of Excellence to engage in applied research in strategic regional sectors in close association with leading businesses. The Centers of Competence aim to build competitive research and promote a high level of international visibility. In addition, policy makers may develop collaborative research projects and knowledge exchange involving one or more business partners with one or more public research institutes to engage in specific $R \& D$ projects with commercial purposes.

2. The creation of an intermediary organization that helps supply and demand for new technologies that can take the form of an R\&D center for a business incubator.

3. The use of an open digital innovation platform to connect research centers with micro, small, and medium enterprises (MSMEs).

4. Development of new programs to support university spinoffs, which are defined as start-ups created to commercially exploit some knowledge, technology, or research output developed at the university (Pirnay, Surlemont, \& Nlemvo, 2002), as direct spin-offs take advantage of knowledge from universities.

Thus, the relationships and networks that are established will be able to create strong social capital not only at the individual level, but also at the structural level. Currently the government has taken a stance to bridge the relationship between universities and industry in order to find a common frame of mind before discussing long-term partnership programs. Hope, problem conception This has been resolved, the relationship between universities, government, and industry creates a harmony that supports the development of human resources and economic development.

Universities take various strategies to improve relationships cooperation between universities and industry. The consequences of the strategy must be seen, planned, and implemented by universities related to policies, as follows:

1. Curriculum (on campus, e-learning and off campus)
2. Curriculum administration (across study programs, across faculties, across domestic and foreign universities)

3. Budgeting

4. Collaboration across study programs, faculties, universities

5. Cooperation across the business world and the world of work

6. Cross-country cooperation

In realization, there are several types of cooperation that have been carried out by universities, including university business cooperation, namely cooperation in R\&D, academic mobility, student mobility, commercialization of R\&D results, curriculum development, lifelong learning, and entrepreneurship.

\section{B. Description of success factors}

Collaboration between universities and industry tends to be mutually beneficial if both parties are able to manage it well, but it should be anticipated that there is still a tendency for a low level of interaction between each party. This is due to various reasons, which are essentially related to differences in perspectives (perspectives) between universities (in this case faculties) and industry which can hinder the process of cooperation and hinder the achievement of common goals.

From a faculty point of view:

1. Tend to cooperate with companies that invest more in research and development (R\&D) and human resources who are committed and highly dedicated in carrying out these tasks, so that through this collaboration both parties can share experiences in terms of habits, communication, ways of working, and organizational culture.

2. Not too familiar with the market and industrial culture.

3. Still don't understand the regulations in the market.

4. Do not yet understand the mechanism for disseminating technology offerings and scientific research results.

5. It is still necessary to continue to harmonize the dissemination of scientific research results because the route and distribution mechanism are not yet clear.

6. It is difficult to inform, explain and convey to business or industry partners what the university has been doing and how research can be used by industry.

From an industry point of view:

1. It is difficult to place technology in the industry as a competitive advantage factor to adopt a strategy based on intangibles or technology.

2. Investment in intangible factors, such as product quality, delivery time, marketing access and direct access to consumers is not easily accepted and recognized by the industry as a fundamental tool to compete.

3. False perception of academic reality.

4. Tend to assume that research and technological development activities carried out in academia are too developed or sophisticated and are used specifically to solve practical problems (Daghfous, 2004).

5. Academics are less reliable and cannot be trusted that academics can develop effective solutions. For this reason, a knowledge transfer mechanism is needed from universities to industry. University and industry collaboration is carried out to achieve the goal, namely the 
transfer of knowledge from universities to industry. Several mechanisms of knowledge transfer from universities to industry include (Siegel et al., 2003a; Siegel et. al. 2003b; Lee and Win, 2004): (1) Collegial exchanges, seminars, and publications, are informal in which information exchange occurs. between universities and industry through presentations in seminars, publication of writings through scientific journals and scientific magazines. This collaboration is the first step of a policy of cooperation between universities (especially research centers) and the industrial sector; (2) Consultation and provision of technical services; this form of cooperation emphasizes one or more universities or research centers that are responsible for providing advice, information, and technical services to the industrial sector. The benefits felt by universities in collaborating with industry include:

1. Increased knowledge absorption capacity

2. Contribute to a greater and more detailed understanding of production flows, scientific practices and trends in new and stimulating research areas.

3. Increasing industrial productivity and educational efficiency in higher education,

4. Combining theory and practice to speed up the learning process,

5. Facilitate the transfer of knowledge to the field of production,

6. Optimizing the use of resources (HR, capital, technology, natural resources) for sustainable development.

Collaborative cooperation carried out by universities must look at the typology, as stated by Thomas Deisinger (2010), namely:

a. Research collaboration, including basic and applied research

b. Development of joint initiatives to strengthen the employability of graduates

c. Curricular collaboration through joint study programs

d. Company internships and training programs during and after graduation

e. Professor funding by industry

f. Private colleges funded by industry and the public sector

g. General activities to increase student interest in more applied and/or technology-oriented higher education programs.

To achieve this goal, the main thing that must be done is to solve the problem of the gap between universities and industry by creating a knowledge transfer process through collaboration between faculty and industry. As explained by Mattoon (2006), that the main challenge for universities as higher education institutions is how to transfer the right knowledge and skills for graduates to be absorbed in the industrial world, so that they can make a real contribution to the development of the industrial world.

Through this collaboration, it is hoped that both parties can invest in developing research capabilities that focus on the research area of both parties and find the best solution to the problems they face. In the end, cooperation will have an impact on national economic growth. Universities can provide an increase in the knowledge-based economy through mutually beneficial cooperation with industry, the impact is also expected to be felt by the community through the empowerment of MSMEs.

\section{PEER REVIEWED}

\section{IMPROVEMENT AS PER REVIEWER COMMENTS}

\section{CONCLUSION AND RECOMENDATION}

\section{A. Conclusion}

The Ministry of Education, Culture, Research, and Technology has substantially made substantial changes to the Higher Education System, through the MBKM program. The faculty is required to make various adjustments in response to these changes. The old paradigm that is oriented to teaching (learning oriented) which focuses on the cognitive aspect, must be changed to a blended learning paradigm that empowers students in affective and psychomotor aspects.

Education must be directed at changing values and patterns think(mindset) of students, from just pursuing grades or degrees to mastering science and applying knowledge in life practice. This adjustment is expected to produce graduates who are not only good academically, but also good at problem solving.

Collaboration between faculties and industry is very much needed as the implementation of the MBKM program. Cooperation can be developed in various forms of programs and activities, which focus on developing human resources, both lecturers and students, as well as contributing to the handling of problems faced by the industrial world. Faculty and industry benefit from each other by organize collaboration, with the prerequisites that management is carried out properly, among others regarding the differences between the perception of the faculty and the perception of the world industry regarding the substance of collaboration Among-both parties.

From the results of interviews in the research, it was found that these differences in perceptions, for example: in relation to MBKM, the faculty found it difficult to convert student internship experiences in the industrial world into credits, while there was still an assumption in the industry that internship programs were only a hassle and bother production process.

In addition, through collaboration with the industrial world, the faculty is expected to be able to apply lecture materials into entrepreneurial practice, introducing students to the real work environment. This will be beneficial for students after graduating and entering the world of work. For this reason, lecturers are also required to be able to provide lecture materials that are in accordance with technological developments and the actual business environment. Therefore, the faculty must develop an adaptive curriculum in response to industry demands. Thus, link and match can run more optimally.

\section{B. Recommendation}

Based on the description above, some recommendations that can be submitted are:

1. Faculties need to update the curriculum to match the spirit of MBKM, which is reality-based and responsive; not only oriented to teaching cognitively, but oriented to education 
oriented to affective and psychomotor aspects. The implementation is, graduates are proficient and able to solve problems (problem solving) and have a leadership spirit (leadership).

2. Faculties need to take various steps to improve the competence of lecturers, so that they too can adapt to technological developments, the business environment, and principle-principles in MBKM. Thus, it is hoped that lecturers will be able to apply blended learning, through lecture materials that are realistic and in accordance with reality, and motivate students to become graduates who are not only cognitive-academic, but also smart in developing their knowledge in society, work, entrepreneurship, and education. solve the problems encountered.

3. Faculties carry out various collaborations with the industrial world, starting with an MoU, then a cooperation agreement (PKS), and implementing activities. So far, many MoUs between faculties and industry have stopped on paper. That is why, the faculty must actively follow up the MoU and PKS into real follow-up. The MoU and PKS must be developed to various parties as a step to build alliances, which in turn provides benefits for improving the quality of graduates, institutional capacity, and community empowerment.

4. Faculties need to improve collaborative classes by involving practitioners in the industrial world, so as to provide added value to students, as well as the first step for students to enter the industrial world.

5. The faculty carries out institutional branding, including through developing relationships with various stakeholders. In addition, it is also necessary to organize events, both academic and more popular in nature, associated with millennials, so that they better meet the wishes and needs of the community.

6. Faculties need to improve facilities and infrastructure to support the development of the quality of the teaching and learning process, which ultimately improves the quality of graduates.

7. Broadly speaking, faculties must take concrete steps to adjust values and mindsets in accordance with MBKM principles.

\section{ACKNOWLEDGMENT}

We would like to acknowledge the support of Directorate General of Higher Education, Research, and Technology who provided a grant at the Universitas 17 Agustus 1945 Semarang with Agreement No. 471/PPK/Kerma/PKS/2021.

\section{REFERENCES}

[1] Anatan, L. (2008). University-Industry Collaboration: A Conceptual Review of University-to-Industry Knowledge Transfer Mechanisms. Journal of Management, Vol. 8(1), 26.

[2] Banal-Estañol, A., Jofre-Bonet, M., \& Lawson, C. (2015). The double-edged sword of industry collaboration: Evidence from engineering academics in the UK. Research Policy, 44(6), 1160-1175. https://doi.org/10.1016/j.respol.2015.02.006

[3] Draghici, A., Baban, C.-F., Gogan, M.-L., \& Ivascu, L.-V. (2015). A Knowledge Management Approach for The University-industry Collaboration in Open Innovation. Procedia Economics and Finance, 23(October 2014), 23-32. https://doi.org/10. 1016/s2212-5671(15)00377-9

[4] Fernandez, R. (2015). Collaboration between universities and business in the UK. NCUB National Center for Universities and Business. https://www.ncub.co.uk/index.php?option=com_docman\&view=download \&alias=335-state-of-the-relationship-may$2015 \&$ category_slug $=$ reports $\&$ Itemid $=2728$

[5] Healy, A., Perkmann, M., Goddard, J., \& Kempton, L. (2014). Measuring the impact of university-business cooperation (full report). Publications Office of the European Union, Final Rpor, 100. http://bookshop.europa.eu

[6] Iqbal, AM, Khan, AS, Bashir, F., \& Monday, AA (2015). Evaluating national innovation system of malaysia based on university-industry research collaboration: A systems thinking approach. Asian Social Science, 11(13), 45-60. https://doi.org/10.5539/ass.v11n13p45

[7] Ivascu, L., Cirjaliu, B., \& Draghici, A. (2016). Business Model for the University-industry Collaboration in Open Innovation. Procedia Economics and Finance, 39(November 2015), 674-678. https://doi.org/10.1016/s22125671(16)30288-x

[8] Kolb, DA (1984). Experiential Learning: Experience as the source of learning and development. Englewood Cliffs, NJ: Prentice-Hall.

[9] Law, KMY, \& Chuah, KB (2004). Project-based action learning as learning approach in learning organisation: the theory and framework. Team Performance Management: An International Journal, 10(October), 178-186. https://doi.org/10.1108/

[10] Pudjiarti, ES, \& Hutomo, PTP (2020). Innovative work behaviour: An integrative investigation of person-job fit, person-organization fit, and person-group fit. Business: Theory and Practice. https://doi.org/10.3846/btp.2020.9487

[11] Sonnenwald, DH (2007). Scientific collaboration. Annual Review of Information Science and Technology, 41, 643-681. https://doi.org/10.1002/aris.2007.1440410121

[12] Sugiyanti, D., Nurhadi, D., Department, D., Engineering, P., \& University, M. (2013). Implementation of the Cooperation Program. 1, 63-77.

[13] Wilson, T. (2012). A Review of Business-University Collaboration. Christopher Millward Higher Education Funding Council for England, February 2012

[14] Zakaria, N., Amelinckx, A., \& Wilemon, D. (2004). Working Together Apart? Building a Knowledge-Sharing Culture for Global Virtual Teams. Creativity and Innovation Management, 13(1), 15-29. https://doi.org/10.1111/j.1467-8691.2004.00290.x

\section{AUTHORS}

First Author - Suparno, Faculty of Social and Political Sciences, 17 August 1945 University Semarang

Second Author - Harsoyo, Faculty of Social and Political Sciences, 17 August 1945 University Semarang

Third Author - Adi Ekopriyono, Faculty of Economics and Business, 17 August 1945 University Semarang 